\title{
Religião católica, evangélica e afro-brasileira em disputa eleitoral: acionamento de elementos religiosos na campanha à Assembleia Legislativa do Paraná
}

\begin{abstract}
Resumo
Neste artigo, discutimos a campanha eleitoral de 26 candidatos, identificados como agentes religiosos por ocasião da eleição à Assembleia Legislativa do Paraná (ALEP), em 2014. A abordagem se dá no sentido de inventariar e compreender as evocações da religião, bem como de evidenciar elementos e relações que vêm se mostrando recorrentes na política paranaense e que poderão estar presentes nos próximos pleitos. As fontes, que compreendem os materiais de campanha divulgados pelos candidatos, compostos por flyers, santinhos, jingles, entrevistas, vídeos, entre outros, foram coletadas durante o período de campanha. $\mathrm{Na}$ análise e sistematização do material empírico, são construídos três eixos de análise que permitem compreender as formas de operacionalização mútua entre religião e política no tempo da eleição: intensidade, estilo e forma de acionamento religioso na campanha eleitoral. Os resultados evidenciam elementos comuns às campanhas eleitorais de agentes religiosos, que podem ser úteis para balizar novas análises, e contribuem para a compreensão das relações entre política e religião no cenário paranaense, na medida em que identificam os sujeitos envolvidos, evidenciam as estratégias e alianças entre diferentes partidos políticos e grupos sociais.
\end{abstract}

Palavras-chave: Eleições - Paraná. Deputados Estaduais - Eleições

- Paraná. Campanha Eleitoral - Paraná. Religião e Política.

Candidatos Políticos.

\section{Frank Antonio Mezzomo}

Doutor em História pela Universidade

Federal de Santa Catarina (UFSC).

Professor na Universidade Estadual do Paraná (UNESPAR).

Campo Mourão - PR - BRASIL

frankmezzomo@gmail.com

orcid.org/0000-0003-0968-6777

\section{Cristina Satiê de Oliveira Pátaro}

Doutora em Educação pela Universidade de São Paulo (USP). Professora na

Universidade Estadual do Paraná (UNESPAR).

Campo Mourão - PR - BRASIL

crispataro@gmail.com

orcid.org/0000-0003-4907-7722

\section{Para citar este artigo:}

MEZZOMO, Frank Antonio; PÁTARO, Cristina Satiê de Oliveira. Religião católica, evangélica e afro-brasileira em disputa eleitoral: acionamento de elementos religiosos na campanha à Assembleia Legislativa do Paraná. Tempo e Argumento, Florianópolis, v. 11, n. 26, p. 456 - 485, jan./abr. 2019. 


\title{
Catholic, evangelical and Afro- Brazilian religion in electoral dispute: use of religious elements in the campaign to the Legislative Assembly of
}

\section{Paraná}

\begin{abstract}
In this paper, we discuss the electoral campaign of 26 candidates, identified as religious agents on the 2014 election to the Legislative Assembly of Paraná (ALEP). The approach is to inventory and understand the evocations of religion, as well as evidence recurrent elements and relationships in Paraná politics and that may be present in the next elections. The sources were collected during the campaign period and include the campaign materials released by the candidates: leaflets, jingles, interviews, videos, among others. In the analysis and systematization of the empirical material, three axes of analysis are constructed that allow the understanding of the ways of mutual operationalization between religion and politics in the time of the election: intensity, style and form of religious activation in the electoral campaign. The results show common elements to electoral campaigns of religious agents, which can be useful to conduct new analyzes, and contribute to the understanding of the relations between politics and religion in the Paraná scenario, once they identify the subjects involved and evidence the strategies and alliances between different political parties and social groups.
\end{abstract}

Keywords: Elections - Paraná. State Deputies - Elections Paraná. Electoral Campaign - Paraná. Religion and Politics. Political Candidates. 
“Ratinho Junior recebeu o apoio da Igreja Quadrangular, em congresso da igreja encerrado no domingo"; “Igreja dá um chega pra lá no deputado pastor Praczyk”; “Igreja Universal tentará eleger dois novos pastores no Paraná em 2018”; "Noêmia Rocha não terá apoio da Assembleia de Deus na eleição de 2018”; “Assembleia de Deus do Paraná aprova em convenção Misael Junior como pré-candidato a deputado estadual". Essas notas publicadas pela imprensa eletrônica paranaense nos últimos meses de 2017, identificadas aleatoriamente, evidenciam que já foi dada a largada para a corrida às eleições de 2018 no Estado, quando, ao mesmo tempo, os candidatos esgrimam-se por apoios das Igrejas, e estas, por sua vez, começam a se organizar para garantir seus “representantes religiosos" nos espaços decisórios de poder do Estado. As alianças vão se formando, os grupos vão se definindo e os projetos se delineando, a fim de garantir uma base eleitoral e, consequentemente, êxito para as próximas eleições, em que estarão em disputa vagas ao executivo e legislativo estadual e federal. Em um país em que a Constituição da República dispõe acerca da laicidade do Estado, religião e política não parecem fazer muita cerimônia para atuarem conjuntamente (MARIANO, 2011; GIUMBELLI, 2011).

Diante das movimentações que vêm ocorrendo entre os campos político e religioso no Paraná, e em vista de analisar de que forma se constitui essa dinâmica, este artigo pretende discutir as candidaturas de agentes religiosos na última eleição para a Assembleia Legislativa do Estado do Paraná (ALEP), ocorrida em 2014. A importância dessa abordagem se dá em uma dupla direção: inventariar e compreender as evocações da religião no pleito de 2014; e servir de base para a construção de elementos que vêm se mostrando recorrentes na cultura política paranaense e que poderão estar presentes novamente nos próximos pleitos, como, aliás, sugerem as notas anteriormente apresentadas. Ainda, vale o destaque de que não foi identificada, até o momento, nenhuma pesquisa que inventariasse as candidaturas de agentes religiosos no Estado do Paraná, tampouco que pautasse essa temática da instrumentalização mútua entre religião e política em tempo de eleição, como já ocorre em outros estados brasileiros (MACHADO, 2006; MIRANDA, 2006; ORO; MARIANO, 2009; PROCÓPIO, 2014; BANDINI, 
2004). Reside aqui, mais um motivo da relevância das investigações que vêm sendo desenvolvidas acerca desta temática

Ao enfocarmos a campanha eleitoral dos agentes religiosos à ALEP, é válido ressaltar que se trata de um período que explicita estratégias e relações de poder de diferentes grupos sociais, demarcando o denominado tempo da política, ou tempo da eleição (PALMEIRA, 2002; CERVI, 2010). O período eleitoral, assim, é quando relações de poder, mídias, grupos e organizações partidárias são mobilizados, fazendo com o que o eleitor passe a prestar atenção ao cenário político, sendo invocado a participar dos pleitos como agente e protagonista. Cria-se, ainda, um cenário de disputa explícita, de separação, rituais e interdições autorizados, de modo que "mais do que a escolha de representantes ou governantes, parece estar em jogo um rearranjo de posições sociais" (PALMEIRA, 2002, p. 172). Assim, compreendemos que as eleições constituem um lócus privilegiado de análise, tendo em vista que, nesse período, religião e política intensificam seus diálogos, trincheiras e acordos, evidenciando, por conseguinte, a existência de uma instrumentalização mútua entre essas duas esferas sociais (ORO; CARVALHO JÚNIOR, 2015).

Os dados aqui analisados foram coletados durante o período de campanha das eleições de 2014, entre os meses de agosto e outubro. Além das informações disponibilizadas pelo site do Tribunal Superior Eleitoral (TSE), foram identificados os materiais produzidos e veiculados na internet durante a campanha eleitoral, tanto pelos próprios candidatos quanto pelos partidos/coligações e também pelas igrejas, tais como: panfletos; santinhos; propaganda eleitoral gratuita veiculada em rádio e televisão; blogs e fanpage dos candidatos; jingles; fotos e vídeos de reuniões e passeatas; notas e moções de apoio, em especial divulgados pelas instituições religiosas; entrevistas ou informes publicados na imprensa estadual. Todos os materiais foram baixados, organizados e tabulados, e encontram-se sob a guarda do Grupo de Pesquisa Cultura e Relações de Poder.

\footnotetext{
1 O Grupo de Pesquisa Cultura e Relações de Poder vem tematizando, a partir de uma abordagem interdisciplinar, as imbricações entre religião e política no Estado do Paraná, notadamente em eleições proporcionais municipais e estaduais. Atualmente, encontra-se em andamento a investigação "Agentes religiosos na Assembleia Legislativa do Estado do Paraná: articulações entre religião e política na campanha eleitoral", com apoio financeiro do CNPq e da Fundação Araucária, da qual este artigo traz resultados parciais.
} 
Vale ressaltar que, para a identificação dos materiais de campanha, foram considerados aqueles candidatos que, por meio dos materiais e dos dados disponibilizados no TSE, ficavam evidenciados ao menos um dos seguintes critérios: apoio de instituição religiosa; exercício de função junto à instituição eclesiástica (pastor, padre, missionário, evangelista, etc.), dado pela sua biografia ou por seu nome de urna; uso de elementos religiosos na divulgação de sua candidatura, ainda que não se tenha declarado abertamente a vinculação a uma determinada religião. Tais critérios compõem o perfil daqueles candidatos que podem ser caracterizados como agentes religiosos (ORO, 2001). Não obstante a observância de tais critérios, é possível que algum candidato possa não ter sido identificado pela pesquisa, uma vez que a busca se limitou aos materiais disponibilizados na internet durante o período de campanha eleitoral.

Em 2014, o Estado do Paraná contava com 7.853.968 eleitores. No primeiro turno das eleições, ocorrido em 05 de outubro, compareceram às urnas um total de 6.536.251 eleitores, cerca de $83,15 \%$ do total (TSE, 2014). Na disputa pelo Palácio do Iguaçu, sede do governo do Estado do Paraná, concorreram oito candidatos, dentre os quais os principais foram: Beto Richa (PSDB) - então governador, que pleiteava a reeleição; Roberto Requião (PMDB) - então Senador da República, e que havia ocupado o governo do Paraná de 1991 a 1994 e entre 2003 e 2010; Gleisi Hoffmann (PT) - candidata derrotada em 2010 para o governo do Estado, e que atuava no momento junto ao Senado. A Tabela 1, a seguir, apresenta as coligações partidárias que configuraram nas eleições de 2014, bem como o quantitativo de votos obtidos por cada chapa:

Tabela 1: Candidatos e coligações que disputaram o governo do Estado do Paraná em 2014

\begin{tabular}{llcc}
\hline \multicolumn{1}{c}{ Chapa } & Nome da coligação & \multicolumn{1}{c}{ Partidos } & Votos \\
\hline $\begin{array}{l}\text { Beto Richa } \\
\text { (Vice: Cida Borghetti) }\end{array}$ & Todos pelo Paraná & PSDB, PROS, PSD, PSB, DEM, PPS, PSC, & $55,67 \%$ \\
& & $\begin{array}{l}\text { PR, SD, PSL, PSDC, PMN, PHS, PEN, PP, } \\
\text { PTdoB, PTB }\end{array}$ & $(3.301 .322)$ \\
\hline $\begin{array}{l}\text { Roberto Requião } \\
\text { (Vice: Rosane Pereira) }\end{array}$ & Paraná com Governo & PMDB, PV, PPL & $27,56 \%$ \\
\hline $\begin{array}{l}\text { Gleisi Hoffmann } \\
\text { (Vice: Haroldo Ferreira) }\end{array}$ & Paraná olhando pra & PT, PDT, PCdoB, PTN e PRB & $(1.634 .316)$ \\
\hline
\end{tabular}

Fonte: TSE, 2014. 
Na disputa, a coligação “Todos pelo Paraná” obteve êxito na reeleição de Beto Richa ainda no primeiro turno, conquistando 55,67\% dos votos e compondo a maioria das 54 vagas da Assembleia Legislativa do Paraná (ALEP).

\section{Agentes religiosos na disputa à ALEP}

Em vista de analisar as candidaturas de agentes religiosos à ALEP, uma das variantes que deve ser considerada é o pertencimento religioso da população paranaense. Observando a distribuição da população brasileira (Tabela 2), verificamos que a maioria se declara católica (64,63\%), seguida dos evangélicos $(22,16 \%)$, sendo que as religiões de matriz afro-brasileira representam 0,31\%. Já no Paraná, identificamos que o percentual de evangélicos é bastante semelhante ao perfil nacional, embora haja uma maior concentração de católicos (69,59\%) e uma representatividade significativamente menor de adeptos às religiões de matriz afro-brasileira (0,09\%).

Tabela 2: Distribuição da população nas religiões católica, evangélicas e afro-brasileiras

\begin{tabular}{lrrrr}
\hline \multirow{2}{*}{ Religião } & \multicolumn{2}{c}{ Brasil } & \multicolumn{2}{c}{ Paraná } \\
\cline { 2 - 5 } & \multicolumn{1}{c}{ Qtd. } & \multicolumn{1}{c}{$\%$} & \multicolumn{1}{c}{ Qtd. } & $\%$ \\
\hline Católica & 123.280 .172 & 64,63 & 7.268 .935 & 69,59 \\
\hline Evangélicas & 42.275 .440 & 22,16 & 2.316 .213 & 22,18 \\
\hline Afro-brasileiras & 588.797 & 0,31 & 8.949 & 0,09 \\
\hline Total & $\mathbf{1 9 0 . 7 5 5 . 7 9 9}$ & $\mathbf{1 0 0 , 0 0}$ & $\mathbf{1 0 . 4 4 4 4 . 5 2 6}$ & $\mathbf{1 0 0 , 0 0}$ \\
\hline
\end{tabular}

Fonte: IBGE (2010) e IBGE-Cidades (2010).

É em consonância com esse cenário de pertencimento religioso que se constroem as candidaturas, sobremaneira aquelas que optaram por recorrer a elementos religiosos em suas campanhas. A esse respeito, verificamos que, nas eleições proporcionais para Deputado Estadual - foco da presente investigação -, concorreram 736 candidatos para o preenchimento das 54 cadeiras da ALEP, sendo que, deste total, 26 foram identificados como agentes religiosos, cujos vínculos institucionais se davam com diferentes religiões: catolicismo, matriz afro-brasileira e evangélicas, essas distribuídas em 13 diferentes denominações. Dentre os candidatos, é possível identificar padres, missionários, bispos, pastores e membros/fiéis que mencionaram em seus materiais de campanha e discursos o pertencimento religioso e, em diversos casos, apoio eclesiástico à sua candidatura. 
Quanto à filiação partidária, pudemos verificar que se referem a partidos políticos de matriz ideológica de direita, sendo eles: DEM, PEN, PMDB, PMN, PP, PPS, PR, PRB, PRP, PSC, PSD, PSDB, PSL, PTN, PV, SD. A esse respeito, destacamos a vinculação de cinco candidatos ao PSC e três ao PP. Dos 26 candidatos identificados, cinco foram eleitos e um dos que ficou como suplente assumiu logo no $2^{\circ}$ mês de mandato. A tabela a seguir apresenta a informação dos agentes religiosos que concorreram à ALEP em 2014:

Tabela 3: Candidatos à ALEP em 2014 que recorreram a elementos religiosos durante a campanha eleitoral

\begin{tabular}{|c|c|c|c|c|}
\hline Nome de campanha & Partido & Vinculação religiosa & Situação & Votos \\
\hline Evandro Araújo & PSC & Igreja Católica & Suplente $(*)$ & 23.233 \\
\hline Gessani & PP & Igreja Católica & Suplente & 16.938 \\
\hline Jura & PSD & Igreja Católica & Suplente & 33.892 \\
\hline Padre Roque & PR & Igreja Católica & Suplente & 6.660 \\
\hline Cantora Mara Lima & PSDB & Igreja Assembleia de Deus & Eleita & 43.549 \\
\hline Cantora Mirian & PSDB & Igreja Assembleia de Deus & Suplente & 549 \\
\hline Clayton Costa Rosa & $\mathrm{PP}$ & Igreja Assembleia de Deus & Suplente & 5.496 \\
\hline Missionária Janine & PMN & Igreja Assembleia de Deus & Suplente & 425 \\
\hline Noemia Rocha & PMDB & Igreja Assembleia de Deus & Suplente & $15 \cdot 357$ \\
\hline Pastor Elias de Oliveira & PEN & Igreja Assembleia de Deus & Não eleito & 1.996 \\
\hline Queiroga & DEM & Igreja Assembleia de Deus & Não eleito & 10.350 \\
\hline Evangelista Balbino & PRP & Igreja Batista Nacional & Não eleito & 389 \\
\hline Neri Tavares & PTN & Igreja Batista Nova Aliança & Não eleito & 247 \\
\hline Pastor Dã Cortez & PSD & Igreja Batista Betel & Suplente & 8.581 \\
\hline Nelson Lopes & PPS & Igreja Metodista & Suplente & 1.335 \\
\hline Pastor Claudionor Rodrigues & SD & Igreja Metodista & Suplente & 264 \\
\hline Pastor Edson Praczyk & PRB & Igreja Universal do Reino de Deus & Eleito & 47.797 \\
\hline Gilson de Souza & PSC & Igreja do Evangelho Quadrangular & Eleito & 34.470 \\
\hline Missionário Ricardo Arruda & PSC & Igreja Mundial do Poder de Deus & Eleito & 23.592 \\
\hline Dr. Ulisses & PSL & $\begin{array}{c}\text { Igreja Internacional da Graça de } \\
\text { Deus }\end{array}$ & Não eleito & 8.863 \\
\hline Clark Crente & PSC & Igreja Evangélica Templo das Águias & Suplente & 2.214 \\
\hline Claudia Pereira & PSC & Igreja Congregação Cristã do Brasil & Eleita & $29 \cdot 379$ \\
\hline Pastora Rose & PSL & Igreja de Cristo Restaurador & Suplente & 156 \\
\hline Pastor João dos Anjos & PTN & $\begin{array}{l}\text { Igreja Evangélica Pentecostal Seara } \\
\text { de Jesus Cristo }\end{array}$ & Não eleito & 1.787 \\
\hline Dourival Simões & PV & Religião Afro-brasileira & Suplente & 878 \\
\hline Pastor Emanuel & PP & Não identificado & Suplente & 392 \\
\hline
\end{tabular}

$(*)$ Assumiu em fevereiro de 2015.

Fonte: Dados da pesquisa. 
Como podemos verificar, o quantitativo tabulado evidencia a porosidade das fronteiras entre os campos religioso e político, e expressa uma presença significativa da religião no pleito eleitoral de 2014, de modo que tal dimensão não pode ser ignorada nas disputas e na própria constituição de uma plataforma eleitoral (CARVALHO JÚNIOR; ORO, 2017).

\section{Analisando as campanhas dos agentes religiosos}

Tendo apresentado o rol de candidatos identificados como agentes religiosos, nosso olhar passa a ser, a partir de agora, o de sistematizar e analisar as campanhas eleitorais, a partir dos materiais organizados para a pesquisa.

Como um primeiro movimento, é válido mencionar que os candidatos fazem uso de elementos religiosos em intensidades e frequências diferenciadas. Assim, dentre os 26 nomes da Tabela 3, podemos identificar um grupo de dez candidatos cuja recorrência aos elementos religiosos é feita pontualmente, em menor intensidade (Tabela 4). Nesses casos, que se referem tanto a campanhas menos expressivas quanto a outras de maior envergadura, tal recorrência se limita ao uso de termos como Pastor ou Evangelista no nome de urna, à menção a Deus ou a passagens bíblicas de modo esporádico nos jingles e demais materiais de campanha, ou ainda na apresentação do candidato como religioso no caso, evangélico - sem que tais referências apareçam como norteadoras de sua campanha, de sua identidade política ou de suas propostas, e tampouco que sua candidatura seja assumida por alguma instituição ou grupo religioso.

Tabela 4: Candidatos à ALEP em 2014 que recorreram pontualmente a elementos religiosos durante a campanha eleitoral

\begin{tabular}{|c|c|c|c|c|}
\hline $\begin{array}{l}\text { Nome de } \\
\text { campanha }\end{array}$ & Vinculação religiosa & Situação & Votos & Recorrência à religião \\
\hline Cantora Mirian & $\begin{array}{l}\text { Igreja Assembleia de } \\
\text { Deus }\end{array}$ & Suplente & 549 & $\begin{array}{l}\text { É cantora gospel e esposa de pastor } \\
\text { evangélico. }\end{array}$ \\
\hline $\begin{array}{l}\text { Pastor Elias de } \\
\text { Oliveira }\end{array}$ & $\begin{array}{c}\text { Igreja Assembleia de } \\
\text { Deus }\end{array}$ & $\begin{array}{l}\text { Não } \\
\text { eleito }\end{array}$ & 1.996 & Nome de urna. \\
\hline
\end{tabular}




\begin{tabular}{|c|c|c|c|c|}
\hline $\begin{array}{c}\text { Nome de } \\
\text { campanha }\end{array}$ & Vinculação religiosa & Situação & Votos & Recorrência à religião \\
\hline Queiroga & $\begin{array}{l}\text { Igreja Assembleia de } \\
\text { Deus }\end{array}$ & $\begin{array}{l}\text { Não } \\
\text { eleito }\end{array}$ & 10.350 & $\begin{array}{l}\text { Identifica-se como o único candidato } \\
\text { evangélico de sua região. Faz menção a } \\
\text { algumas propostas que favoreceram as } \\
\text { igrejas durante seu mandato como } \\
\text { vereador. }\end{array}$ \\
\hline $\begin{array}{l}\text { Evangelista } \\
\text { Balbino }\end{array}$ & $\begin{array}{c}\text { Igreja Batista } \\
\text { Nacional }\end{array}$ & $\begin{array}{l}\text { Não } \\
\text { eleito }\end{array}$ & 389 & $\begin{array}{l}\text { Nome de urna. Na biografia, em seu site de } \\
\text { campanha, menciona o Salmo } 128 .\end{array}$ \\
\hline Neri Tavares & $\begin{array}{c}\text { Igreja Batista Nova } \\
\text { Aliança }\end{array}$ & $\begin{array}{c}\text { Não } \\
\text { eleito }\end{array}$ & 247 & Apresenta-se como pastor evangélico. \\
\hline $\begin{array}{l}\text { Pastor } \\
\text { Claudionor } \\
\text { Rodrigues }\end{array}$ & Igreja Metodista & Suplente & 264 & Nome de urna. \\
\hline Claudia Pereira & $\begin{array}{l}\text { Igreja Congregação } \\
\text { Cristã do Brasil }\end{array}$ & Eleita & 29.379 & $\begin{array}{l}\text { Em alguns materiais, identifica-se como } \\
\text { evangélica. Em um dos jingles de } \\
\text { campanha, menciona "Deus na direção". }\end{array}$ \\
\hline Pastora Rose & $\begin{array}{l}\text { Igreja de Cristo } \\
\text { Restaurador }\end{array}$ & Suplente & 156 & Nome de urna. \\
\hline $\begin{array}{l}\text { Pastor João dos } \\
\text { Anjos }\end{array}$ & $\begin{array}{c}\text { Igreja Evangélica } \\
\text { Pentecostal Seara de } \\
\text { Jesus Cristo }\end{array}$ & $\begin{array}{l}\text { Não } \\
\text { eleito }\end{array}$ & 1.787 & $\begin{array}{l}\text { Nome de urna. Faz menção à bíblia, a Deus } \\
\text { e à sua atuação como pastor. }\end{array}$ \\
\hline Pastor Emanuel & Não identificado & Suplente & 392 & Nome de urna. \\
\hline
\end{tabular}

Fonte: Dados da pesquisa.

Ainda assim, cabe destacar que o acionamento da religião por esses candidatos, mesmo que pouco frequente, não ocorre de maneira fortuita, mas demarca a religião como um dos elementos - embora não central - da imagem pública do candidato em campanha.

Já no caso dos outros 16 candidatos, expressos na Tabela 5, podemos dizer que a recorrência à religião foi, em grande medida, um elemento que orientou a campanha eleitoral, sua identidade política e suas propostas, tendo em vista que os elementos religiosos foram identificados com frequência em materiais de campanha, no apoio eclesiástico e na construção da imagem pública do político, mediante o uso de símbolos bíblia, crucifixo, imagens de santos -, a linguagem - orações, passagens bíblicas, etc. - e os espaços frequentados - templos, igrejas, eventos religiosos, entre outros. Vale ressaltar que tais estratégias de acionamento religioso ocorrem com maior ou menor intensidade nos diferentes candidatos, e em conformidade com o ambiente ou interlocutor com o qual se dá a campanha. 
Tabela 5: Candidatos à ALEP em 2014 que recorreram a elementos religiosos de forma expressiva durante a campanha eleitoral

\begin{tabular}{lcccr}
\hline \multicolumn{1}{c}{ Nome de campanha } & Partido & Vinculação religiosa & Situação & Votos \\
\hline Jura & PSD & Igreja Católica & Suplente & 33.892 \\
\hline Evandro Araújo & PSC & Igreja Católica & Suplente $\left(^{*}\right)$ & 23.233 \\
\hline Gessani & PP & Igreja Católica & Suplente & 16.938 \\
\hline Padre Roque & PR & Igreja Católica & Suplente & 6.660 \\
\hline Cantora Mara Lima & PSDB & Igreja Assembleia de Deus & Eleita & 43.549 \\
\hline Noemia Rocha & PMDB & Igreja Assembleia de Deus & Suplente & 15.357 \\
\hline Clayton Costa Rosa & PP & Igreja Assembleia de Deus & Suplente & 5.496 \\
\hline Missionária Janine & PMN & Igreja Assembleia de Deus & Suplente & 425 \\
\hline Pastor Dã Cortez & PSD & Igreja Batista Betel & Suplente & 8.581 \\
\hline Nelson Lopes & PPS & Igreja Metodista & Suplente & 1.335 \\
\hline Pastor Edson Praczyk & PRB & Igreja Universal do Reino de Deus & Eleito & 47.797 \\
\hline Gilson de Souza & PSC & Igreja do Evangelho Quadrangular & Eleito & 34.470 \\
\hline Missionário Ricardo Arruda & PSC & Igreja Mundial do Poder de Deus & Eleito & 23.592 \\
\hline Dr. Ulisses & PSL & Igreja Internacional da Graça de Deus & Não eleito & 8.863 \\
\hline Clark Crente & PSC & Igreja Evangélica Templo das Águias & Suplente & 2.214 \\
\hline Dourival Simões & PV & Religião Afro-brasileira & Suplente & 878 \\
\hline
\end{tabular}

(*) Assumiu em fevereiro de 2015.

Fonte: Dados da pesquisa.

No intuito de compreendermos os acionamentos dos elementos religiosos no tempo da eleição, e, ainda, em que medida os candidatos apresentam-se como portavozes escolhidos por sua instituição religiosa, apresentamos de modo mais aprofundado as campanhas dos 16 agentes religiosos mencionados, organizando-os pela religião de vinculação.

\section{Igreja Católica}

Vinculados à Igreja Católica, foram identificados quatro candidatos que fizeram uso intenso dos elementos religiosos como estratégia de campanha. Três deles - Evandro Araújo (PSC), Jura (PSD) e Gessani (PP) - receberam o apoio explícito do Ministério Fé e Política, vinculado à Renovação Carismática Católica (MFP/RCC), cuja estrutura e funcionamento no Paraná adota certas especificidades. Enquanto em nível nacional tal ministério visa uma formação política em sentido amplo, sem a intenção assumida de atuar em campanhas eleitorais, no Estado do Paraná sua atuação parece ser mais diretiva, tendo em vista a ação explícita de indicação de candidatos nas eleições para Deputado 
Estadual e Federal em 2014, e a busca de apoios de eleitores nas diferentes paróquias do estado (RCC/Brasil, 2016; RCC/PR, 2013).

Dentre os católicos, Jura (PSD) foi o candidato que obteve maior quantitativo de votos: 33.892, em 333 dos 399 municípios do Paraná, sobressaindo-se em Curitiba (34,38\% dos votos). No entanto, não foi eleito para ocupar uma das cadeiras da ALEP, em virtude de sua legenda partidária. Em 2010, havia concorrido, sem êxito, à disputa para Deputado Federal, já com o apoio da RCC, tendo obtido mais de 60 mil votos. Em sua campanha eleitoral de 2014, contou com o apoio de diversas lideranças da Igreja, que, além das articulações promovidas junto aos eleitores, atuaram nas redes sociais, conclamando a todos para a eleição de Jura, afinal sua participação junto à ALEP representaria "um projeto de Deus, do Bem, da defesa de nosso povo, da nossa religião".

Evandro Araújo (PSC) foi vereador em Marialva entre 2005 e 2008, e vice-prefeito entre 2009 e 2010, quando participou pela primeira vez da disputa à ALEP, já com apoio do MFP/PR, conquistando, na ocasião, 34.169 votos, mas não sendo eleito. Sua campanha de 2014 - que envolveu postagens nas redes sociais e visitas a diversas igrejas e comunidades, em especial da região de Marialva, Maringá e Londrina - ocorreu, em grande parte, em paralelo à campanha de Diego Garcia (PHS), candidato eleito para Deputado Federal e que teve igualmente o apoio oficial do MFP/PR. Nesse sentido, vários dos materiais de campanha veiculavam os dois candidatos, lado a lado, destacando a importância de sua eleição para a concretização de um projeto eclesiástico: "Levantemos nossa pátria de seu abatimento e lutemos por nosso povo e nossa religião" (1M 3:43). Em seus santinhos, a foto de Evandro Araújo aparece ao lado da imagem de uma pomba representando o Espírito Santo - sobre os seguintes dizeres: “É Renovação", em um trocadilho que faz menção tanto à Renovação Carismática Católica quanto à renovação na política paranaense, que sua eleição representaria. Evandro Araújo obteve um total de 23.233 votos, ficando como primeiro suplente de sua coligação e assumindo o mandato em fevereiro de 2015 .

O terceiro candidato apoiado pelo MFP/PR, Gessani, exercia à época seu segundo mandato como vereador em Foz do Iguaçu e concorria também pela segunda vez a uma vaga na ALEP. O candidato apresenta-se como cantor e pregador na Igreja há mais de 20 
anos e, assim como Evandro Araújo e Jura, reforça em sua campanha o apoio oficial recebido da RCC, por meio do MFP/PR, usando inclusive o mesmo slogan: "É Renovação". Recebeu o apoio de membros da Igreja e, dentre suas pautas, afirmou - de forma mais marcante que os outros dois candidatos da RCC - a defesa dos valores éticos e cristãos, da vida e da família tradicional. Gessani alcançou 16.938, oriundos de 148 municípios, dentre os quais se destaca Foz do Iguaçu (30,41\% dos votos).

Já Padre Roque - o quarto candidato católico, mas não vinculado à RCC - foi vereador no município de Londrina de 2009 até 2016, quando se candidatou para seu terceiro mandato, tendo ficado como suplente, assumindo em outubro de 2017. Em seus vídeos de campanha para Deputado Estadual em 2014, Padre Roque aparece transitando pelas ruas, feiras e outros espaços junto à população, recebendo das pessoas mensagens de apoio - enaltecendo sua integridade moral, inteligência, trajetória política -, que são postadas em seu perfil de campanha no Facebook: "ele é pessoa de Deus, ele é um padre... melhor votar em um padre do que em outro político que não conheço" - afirma a eleitora. Ainda durante a campanha, o candidato, expressando sua concepção de religião, afirma ser contrário à Teologia da Prosperidade - numa aversão explícita a determinadas denominações evangélicas -, que transformaria as igrejas em empresas e os crentes em clientes. Padre Roque não foi eleito, tendo obtido um total de 6.660 votos, distribuídos em 94 municípios, cuja maioria (85,81\%) se concentrou em Londrina.

\section{Religiões evangélicas}

Dentre as religiões evangélicas, identificamos oito diferentes denominações às quais se vinculavam os candidatos, com destaque para a Igreja Assembleia de Deus, cujo vínculo foi assumido por quatro candidatos.

\section{Igreja Assembleia de Deus}

Cantora Mara Lima (PSDB), Noemia Rocha (PMDB), Clayton Costa Rosa (PP) e Missionária Janine (PMN) foram os quatro candidatos que assumiram o vínculo com a Assembleia de Deus por ocasião da campanha à ALEP em 2014, sendo que tal acionamento ocorreu de forma diferenciada em cada candidatura. 
Cantora Mara Lima, cantora gospel vinculada à Assembleia de Deus, concorreu, com êxito, ao seu segundo mandato. Com o slogan "Abençoando o Paraná” e pautas direcionadas à mulher e à defesa da família, a campanha de Mara Lima foi bastante expressiva, contando com apoio dos caciques de seu partido no Estado - Beto Richa, concorrendo ao governo do Estado pela segunda vez, e Álvaro Dias, que se elegeu para o Senado com a maior votação das eleições de 2014 - e também de lideranças da Igreja, com destaque para as inserções, em sua campanha, de Marcos Feliciano (PSC/SP), então candidato a Deputado Federal. A cantora gospel foi reeleita com um total de 43.549 votos, sendo a agente religiosa que obteve votos em mais municípios do estado, 391 dos 399 existentes no Paraná.

Noemia Rocha, que obteve a segunda maior votação entre os candidatos da Assembleia de Deus - embora não tenha logrado êxito - era vereadora em Curitiba, eleita em 2012. Durante a campanha, recorreu por diversas vezes a citações bíblicas postadas em seu perfil pessoal do Facebook junto a banners e santinhos, sendo que, em seu material, divulgou ainda, por diversas vezes, que sua candidatura recebeu o apoio oficial da Convenção das Igrejas Evangélicas Assembleia de Deus no Estado do Paraná (Cieadep), definido já em 2013. Noemia Rocha obteve um total de 15.357 votos em 264 municípios do estado, com destaque para Curitiba, onde se concentraram 50,49\% de seus eleitores.

Clayton Costa Rosa já havia atuado como vereador em Rio Branco do Sul, região metropolitana de Curitiba, na gestão 2009-2012. Em sua campanha, o candidato afirma a importância de resguardar os princípios sagrados, sendo que o destaque fica por conta de suas propostas, que têm como prioridade a educação, a saúde, a segurança, e principalmente a família, com o compromisso maior de defesa da família tradicional, "a única sociedade natural", diante daqueles que estariam atuando para extirpá-la do meio social. Em seu material, o candidato anuncia a intenção de levar para as escolas a inclusão dos princípios cristãos e a leitura bíblica em sala de aula. Clayton Rosa não foi eleito, alcançando um total de 5.496 votos, distribuídos em 59 municípios, sendo de Rio Branco do Sul $71,38 \%$ de seus votos. 
Por fim, Missionária Janine apresenta uma campanha modesta, com poucos materiais, mas com recorrência frequente a elementos religiosos. Com o slogan "Toda promessa de Deus passa pelo teste do tempo", foi possível identificar diversas postagens com menção a Deus e, em um dos vídeos compartilhados pela candidata durante a campanha ("Vai para fora, Igreja! Vai para a escuridão brilhar a tua luz"), apresenta um momento de oração de um culto evangélico, no qual se invoca a militância e anuncia: “Nós estamos indo para a política brasileira e as portas do inferno não prevalecerão contra a igreja do Senhor!". Com 425 votos em 19 municípios do estado - 84\% de Foz do Iguaçu -, Missionária Janine não obteve êxito nas eleições de 2014.

\section{Igreja Batista Betel}

Pastor Dã Cortez (PSD) apresenta-se como candidato de Telêmaco Borba município da região Centro Oriental Paranaense, localizado a cerca de 200km de Curitiba -, onde atuou como vice-prefeito na gestão 2013-2016. Em sua campanha, fica explícito o apoio e a expectativa das lideranças do partido (Eduardo Sciarra, presidente do PSD, e do candidato a Deputado Federal Evandro Roman) e fica ainda evidenciado o apoio de alguns pastores de sua Igreja. Em seus vídeos de campanha, faz diversas menções a citações bíblicas, defende a presença de um caráter cristão na política e, ainda, chama a atenção dos eleitores para que escolham bem os "guardiões de Deus para proteger a todos nas esferas federal e estadual”. Pastor Dã Cortez alcançou um total de 8.581 votos em 111 municípios, sendo que Telêmaco Borba representou 73,76\% deste quantitativo.

\section{Igreja Metodista}

Em sua campanha, Nelson Lopes (PPS) faz com frequência um apelo para que os cristãos não se omitam da política, afirmando que tal postura tem possibilitado que os homens sem Deus assumam os postos decisórios nas diferentes instâncias. Com o slogan "Coragem, fé e atitude para propor o novo" e o apoio de amigos e lideranças que voluntariamente se dispuseram a encampar sua candidatura - dentre os quais se destaca o Bispo João Carlos Lopes, presidente da $6^{\text {a }}$ região eclesiástica da Igreja Metodista, que 
agrega os estados do Paraná e Santa Catarina - o candidato propõe a implantação da “boa política e os valores do reino de Deus na vida pública do Paraná”. Totalizando 1.335 votos em 76 municípios, Nelson Lopes não foi eleito, sendo que 59,63\% de seus eleitores estiveram concentrados em Londrina.

\section{Igreja Universal do Reino de Deus}

Candidato oficialmente apoiado pela Igreja Universal do Reino de Deus, o Pastor Edson Praczyk (PRB) foi, dentre os agentes religiosos identificados, o Deputado Estadual eleito com o maior quantitativo de votos, 47.797, distribuídos em 353 municípios do estado. Além disso, foi possivelmente o candidato que apresentou maior volume de material de campanha nas diferentes mídias investigadas, em especial nas redes sociais. Somado a esses fatores, é aquele que acumula maior experiência no Legislativo, tendo em vista ter sido eleito para seu $5^{\circ}$ mandato consecutivo na ALEP. Com o slogan "A diferença que vem de Deus", em referência à passagem bíblica do livro de Malaquias, do Velho Testamento (Ml 3:18), a campanha de Praczyk contou com o apoio de bispos e pastores da Igreja Universal não apenas do Paraná, mas de outros estados, inclusive com menção ao então Senador Marcelo Crivella (PRB/RJ), representante da Igreja a obter maior destaque no cenário político nacional, estando atualmente à frente da prefeitura do Rio de Janeiro. Dentre seu material de campanha, podemos identificar uma série de dez vídeos, nos quais o candidato narra sua trajetória pessoal, buscando evidenciar de que forma a religião marcou sua história de vida, preparando-o para ser "A diferença que vem de Deus" no mundo da política.

\section{Igreja do Evangelho Quadrangular}

Gilson de Souza (PSC) foi líder da $43^{\text {a }}$ Igreja do Evangelho Quadrangular (IEQ) de Curitiba e, em 2014, concorreu para seu segundo mandato na ALEP, tendo sido eleito com apoio oficial da Igreja do Evangelho Quadrangular. Sua campanha foi bastante robusta, com uma participação ativa da instituição religiosa, envolvendo reuniões com pastores de diversas localidades do estado, além de constantes mensagens de apoio divulgadas nas 
redes sociais. Além disso, em diversos momentos, participou de reuniões contando com a presença de lideranças de seu partido, como Pastor Everaldo - que concorria à época para a Presidência da República -, Takayama - candidato a Deputado Federal - e Ratinho Junior - que também disputou uma vaga junto à ALEP. Em diversos materiais de campanha, Gilson de Souza assumia como pauta a defesa da família e o direito de manifestação contra o que seriam práticas imorais e/ou anticristãs, dentre as quais estariam as propostas de descriminalização do aborto e das drogas, e a criminalização da homofobia. Outro destaque de sua campanha é que, em seu primeiro mandato na ALEP, buscou realizar homenagens, destinar emendas parlamentares e criar leis que favoreciam diretamente os evangélicos, em especial a Igreja do Evangelho Quadrangular. Gilson de Souza foi eleito com um total de 34.470 votos, recebidos de eleitores localizados em 333 municípios do Paraná, sendo 34,38\% de Curitiba.

\section{Igreja Mundial do Poder de Deus}

Em sua campanha à ALEP em 2014, Missionário Ricardo Arruda (PSC) contou com apoio maciço do líder máximo da Igreja Mundial do Poder de Deus, o Apóstolo Valdemiro Santiago, que aparece com frequência nos materiais de campanha, sendo seu maior cabo eleitoral. Logo no início da campanha, Ricardo Arruda e sua esposa aparecem em um culto, durante o qual o Apóstolo consagra o casal, em ato que simboliza a unção de seus soldados para a política. Analisando as falas de Valdemiro, fica evidente o esforço de anunciar o candidato como um legítimo representante da obra de Deus, "homem de Deus" e "defensor do evangelho". Nesse movimento, utiliza-se do discurso para mobilizar os telespectadores a atuarem como cabos eleitorais do Missionário Ricardo Arruda, pedindo votos inclusive aos católicos. Sua campanha contou com visitas a igrejas em diferentes municípios do estado, evidenciando uma rede de apoio por partes dos pastores vinculados à instituição religiosa. Ainda durante a campanha, nos dias que antecederam a eleição, Ricardo Arruda divulga a visita do então Governador Beto Richa à Igreja Mundial em Curitiba. Missionário Ricardo Arruda foi eleito com 23.592 votos, distribuídos em 386 municípios do Estado do Paraná, estando concentrados em Curitiba $18,79 \%$ de seus eleitores. 


\section{Igreja Internacional da Graça de Deus}

Em movimento semelhante ao que ocorreu na campanha do Missionário Ricardo Arruda, Dr. Ulisses (PSL) busca se associar ao carisma de R. R. Soares, fundador da Igreja Internacional da Graça de Deus, que foi identificado em alguns dos flyers, banners e fotos de campanha. Com o slogan "Fé e coragem para mudar", e com uma campanha que envolveu visitas em diferentes igrejas do Paraná, o candidato coloca como uma das prioridades de sua proposta a preservação da família tradicional. Dr. Ulisses não foi eleito, obtendo 8.863 votos, distribuídos em mais de 210 municípios do estado, sendo os maiores quantitativos concentrados em Curitiba (cerca de $20 \%$ ) e Cascavel (10\%).

\section{Igreja Evangélica Templo das Águias}

Clark Crente (PSC) assume, para a campanha eleitoral, sua identidade de evangélico - embora não mencione a Igreja à qual se vincula. Em sua trajetória, faz questão de enfatizar sua conversão em 2010, responsável pela cura da síndrome do pânico que o acometia à época. A partir desse momento, deixa de lado uma carreira como modelo para dar mais atenção à dimensão espiritual e aos trabalhos da Igreja. Seu primeiro movimento em direção à política foi em 2012, quando cogitou candidatar-se a vereador em Curitiba e, embora não tenha tido êxito, seu nome político - ligado à figura do Superman, possivelmente por conta de sua semelhança física - foi divulgado pelas redes sociais, ficando amplamente conhecido no estado. Na esteira da constituição de sua identidade política, nas eleições de 2014, seu logotipo de campanha reestiliza o símbolo do super-herói estadunidense, inserindo um crucifixo que faz alusão à religião. Em seus materiais de campanha, afirma representar o povo de Deus e todas as classes, acreditando que sua candidatura se trata de um chamado de Deus diante do qual não pode se omitir. O candidato, assim como Superman, estaria levantando uma geração de guerreiros para mudar a história do povo paranaense. Clark Crente obteve um total de 2.214 votos, em 74 municípios, sendo que $64 \%$ esteve concentrado na capital do estado. 


\section{Religião Afro-brasileira}

Dourival Simões (PV), único representante das religiões de matriz afro-brasileira, realizou sua campanha concentrada nas redes sociais, por conta, segundo o próprio candidato, das dificuldades financeiras. Em seus vídeos de divulgação, não deixa explícita sua pertença religiosa, tampouco sua vinculação à presidência da Federação Paranaense de Umbanda e Cultos Afro-brasileiros (Cebras), embora concentre suas pautas na defesa intensa da liberdade e da tolerância religiosa. Já nas redes sociais, onde o público com o qual interage parece ser mais próximo às causas defendidas, Dourival Simões aciona de forma explícita e constante sua identidade religiosa, por meio de postagens, imagens e notícias, inclusive denunciando ações de intolerância contra os terreiros de umbanda e candomblé e seus participantes. Em um de seus jingles, destaca que "toda a religião e todo povo tem direito à liberdade de expressão" e, em uma de suas postagens de campanha, afirma que chegou "a hora de mostrarmos que os Umbandistas e Candomblecistas podem sim eleger um deputado estadual [...] tenho percebido que é grande a vontade dos irmãos de termos uma representação e lutarmos contra o preconceito, discriminação e intolerância que há tempos estamos sofrendo". Dourival Simões fez 878 votos, alcançando 55 municípios do estado, sendo que 58,2\% esteve concentrado em eleitores curitibanos.

\section{Acionamento da religião na campanha eleitoral: intensidade, estilo e forma}

A partir do material apresentado referente aos 26 candidatos - vinculados a diferentes denominações religiosas -, cabem algumas considerações. Em primeiro lugar, ressalva-se que a utilização de elementos religiosos como estratégia de campanha - em suas diferentes configurações, como discutiremos na sequência - parece não ser suficiente para garantir o êxito eleitoral do candidato, afinal, há outros fatores que influenciam o desempenho eleitoral, que perpassam, por exemplo, a filiação e coligação partidária, a trajetória política do candidato e sua representação regional, além do diálogo e compromissos com os diferentes setores da sociedade. Nesse aspecto, vale acrescentar que, ainda que os candidatos optem por assumir uma identidade religiosa em 
suas campanhas, há sempre outros grupos/setores - de natureza não necessariamente religiosa - com os quais se faz alianças, em vista de obter maior quantitativo de votos.

Como podemos verificar, em todas as matrizes e denominações religiosas analisadas, é flagrante a instrumentalização mútua entre religião e política no período eleitoral, movimento que já vem sendo identificado em outras investigações de mesma natureza. Mais do que uma simples constatação, essa realidade traz repercussões e efeitos de sentido no que se refere ao que devemos entender pela laicidade do Estado, tendo em vista que os arranjos político-religiosos não se limitam a alianças com vistas a obter simplesmente o êxito eleitoral, mas reverberam nos mandatos, bem como nas pautas, decisões e disputas de poder que ocorrem na esfera do espaço público. Essa situação - existente no Brasil e agudizada nas últimas décadas em função da visibilidade e lobby feito pelas religiões, sobretudo católica e evangélicas, junto ao Estado - constitui uma interpretação original, "à brasileira”, do que vem a ser a laicidade, diferentemente do que ocorre em outros países (MARIANO, 2011; GIUMBELLI, 2002).

Não obstante, é preciso destacar que as formas de acionamento da religião no tempo da política são diferenciadas entre os diversos candidatos analisados. A esse respeito, em uma tentativa de sistematização do universo de fontes e sentidos identificados nas campanhas dos agentes religiosos à ALEP em 2014, buscamos construir alguns eixos de análise que permitem compreender as formas de operacionalização mútua entre os campos da religião e da política no tempo da eleição. São eles: intensidade, estilo e forma de acionamento da religião na campanha eleitoral, as quais abordamos de modo mais aprofundado na sequência. Vale mencionar que os eixos aqui construídos encontram-se articulados entre si, e devem ser utilizados com uma finalidade heurística, isto é, em vista de compreender o perfil da campanha e a identidade do candidato agente religioso.

\section{Intensidade no acionamento da religião durante a campanha eleitoral}

Quanto à intensidade, percebe-se que nem todos fazem uso frequente dos elementos religiosos em suas campanhas, como já pode ser verificado quando da 
constituição de dois grupos de candidatos. Assim, vimos que dez dos agentes religiosos analisados apresentam usos pontuais dos elementos vinculados à religião, tendo sido identificados no nome de urna, em menções breves em sua biografia, no uso esporádico de citações bíblicas ou outros recursos ligados à religião (Tabela 4). Nesses casos, não é possível afirmar que o candidato constrói sua imagem política sobre uma identidade religiosa, mas que a religião aparece de modo periférico em sua campanha possivelmente como uma estratégia política.

Já no caso dos outros 16 candidatos, verificamos que trazem uma incorporação mais explícita e intensa da religião em suas identidades, na performance do agente religioso, nos apoios recebidos e nas propostas de campanha priorizadas (Tabela 5).

\section{Estilo de utilização dos elementos religiosos na campanha eleitoral}

Já o estilo de utilização dos elementos religiosos na campanha eleitoral diz respeito ao modo como a religião passa a configurar na construção da identidade do candidato, e que pode ocorrer por diversos meios:

- Vestes e aparência: trata-se das roupas utilizadas, corte de cabelo, maquiagem, entre outros, que, no caso de alguns candidatos, reforçam a identidade religiosa construída (Quadro 1). É o caso, por exemplo, de Missionária Janine, que se apresenta sempre com pouca maquiagem, saias longas e os cabelos compridos; além do traje social utilizado por diversos candidatos, como Missionário Arruda e Pastor Dã Cortez.

Quadro 1: Materiais de campanha de Missionária Janine (foto de urna), Missionário Arruda (vídeo de campanha) e Pastor Dã Cortez (foto de urna)

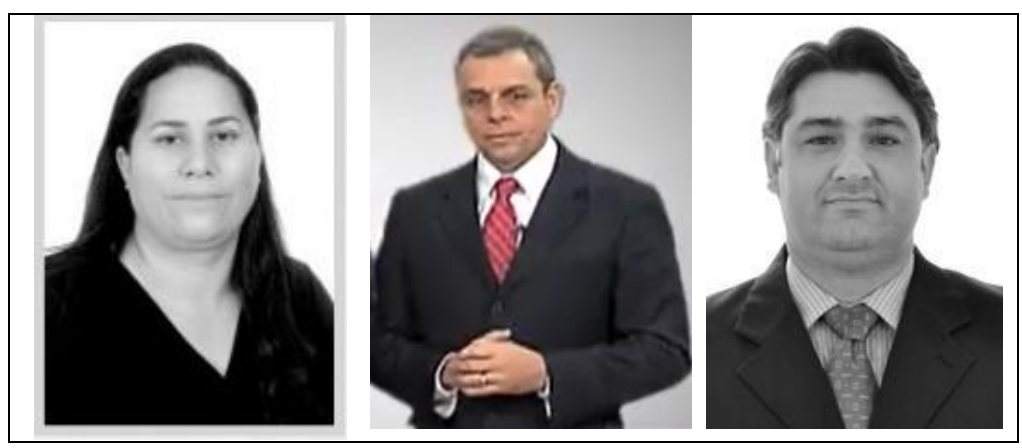

Fonte: Acervo do Grupo de Pesquisa Cultura e Relações de Poder. 
- Uso de símbolos e adereços: refere-se à inclusão de símbolos religiosos crucifixo, bíblia e outras representações imagéticas que fazem alusão à religião (Quadro 2). Durante a campanha eleitoral, alguns candidatos apareciam portando a bíblia - por exemplo, Missionário Arruda -, outros apresentavam em seus santinhos os elementos religiosos: crucifixo - no logotipo de Clark Crente e de Pastor Praczyk -, a representação do Espírito Santo por meio de uma pomba como aparece no santinho de Evandro Araújo -, o uso do terço mariano - que aparece com um dos apoiadores do católico Jura -, entre outros.

Quadro 2: Materiais de campanha de Missionário Arruda (portando a Bíblia), Pastor Praczyk, Clark Crente, Jura (apoiador portanto terço mariano) e Evandro Araújo

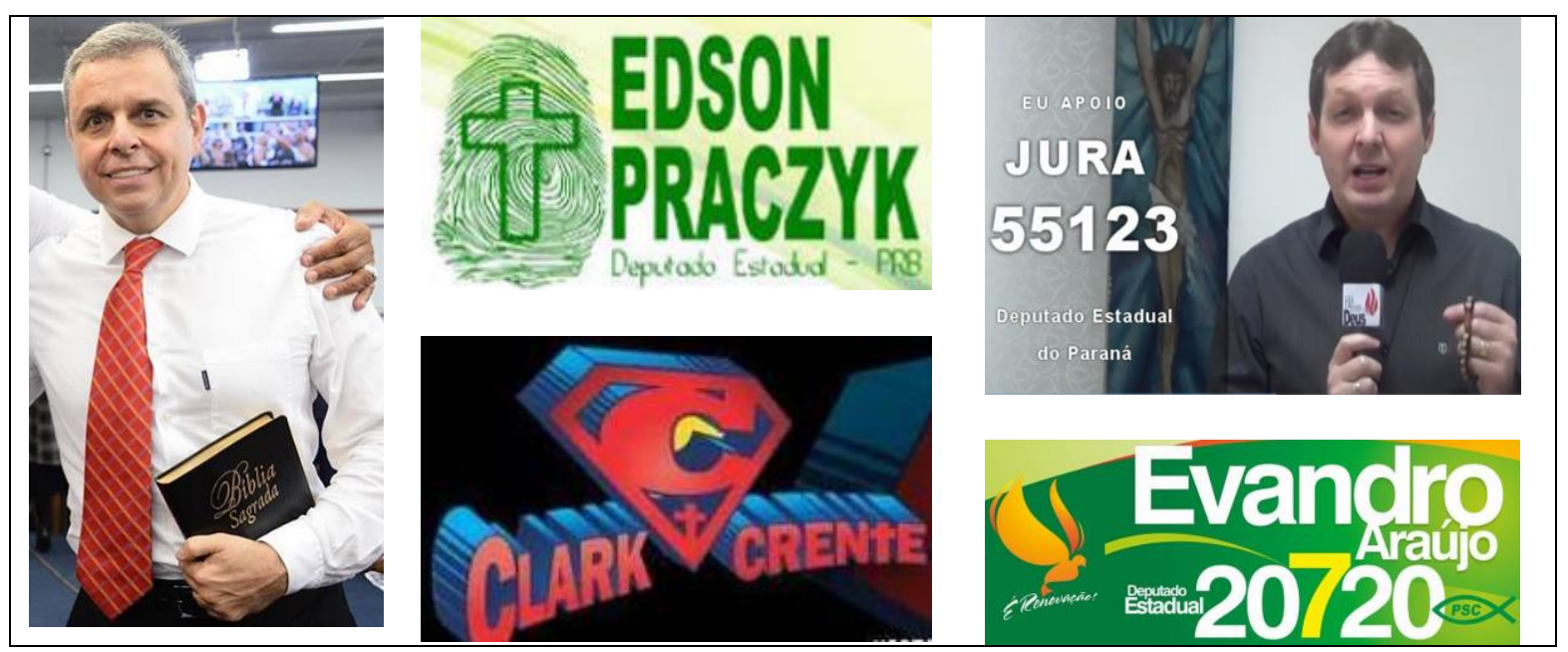

Fonte: Acervo do Grupo de Pesquisa Cultura e Relações de Poder.

- Linguagem: diz respeito à utilização de passagens bíblicas e mensagens religiosas nos materiais de campanha e nos discursos proferidos pelos candidatos, sendo talvez o estilo mais frequentemente acionado entre todos os agentes religiosos. A recorrência à bíblia aparece, por exemplo, no uso de versículos, como o que compõe o slogan da campanha de Pastor Praczyk, ou as mensagens postadas em redes sociais por Pastor Dã Cortez e Noemia Rocha. Em alguns jingles e slogans, igualmente, identifica-se a menção a Deus, à bênção espiritual, à fé, ao caráter 
missionário do candidato - como ocorre com a campanha dos evangélicos Cantora Mara Lima, Nelson Lopes e Claudia Pereira, entre outros - ou mesmo à defesa da liberdade religiosa - como nos materiais de Dourival Simões, em cujo jingle consta: "Pelo fim do preconceito e da intolerância, chega de destruir nação. Toda a religião e todo povo tem direito a liberdade de expressão". Alguns exemplos constam nas imagens do Quadro 3, a seguir.

Quadro 3: Materiais de campanha de Edson Praczyk, Nelson Lopes, Pastor Dã Cortez (postagem de rede social) e Noêmia Rocha

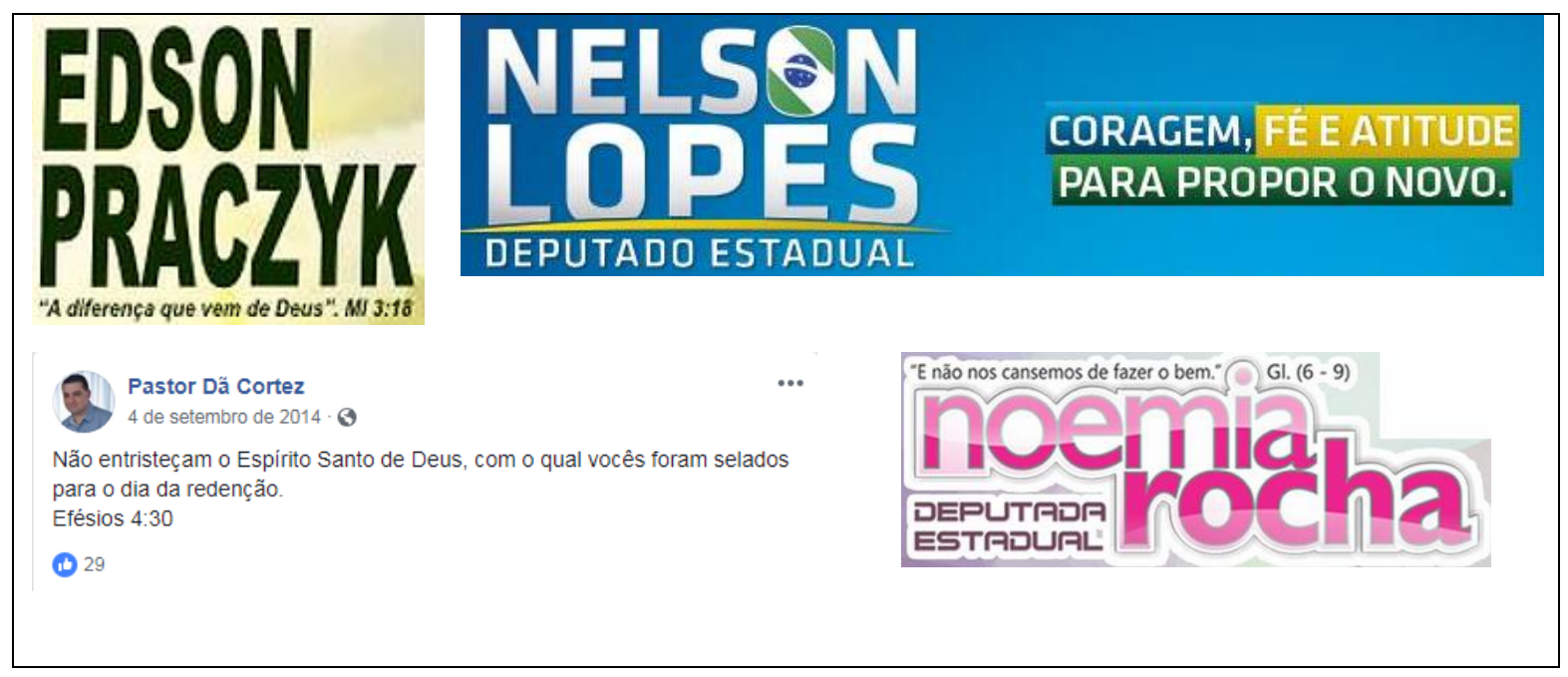

Fonte: Acervo do Grupo de Pesquisa Cultura e Relações de Poder.

- Espaços de campanha: trata-se dos ambientes que remetem a determinada religião, nos quais são realizadas as campanhas. Nesse sentido, a postagem de fotos e vídeos de visitas, cultos, discursos e comícios realizados nas igrejas e nos templos religiosos é um recurso bastante utilizado pelos candidatos, como no caso dos evangélicos Dr. Ulisses e Gilson de Souza, e também dos católicos Jura, Gessani e Evandro Araújo (Quadro 4). Ainda no caso de Dourival Simões, foram identificadas várias postagens ambientadas em terreiros de umbanda e candomblé. 
Quadro 4: Fotos de campanha de Gessani, Gilson de Souza, Mara Lima e Evandro Araújo.

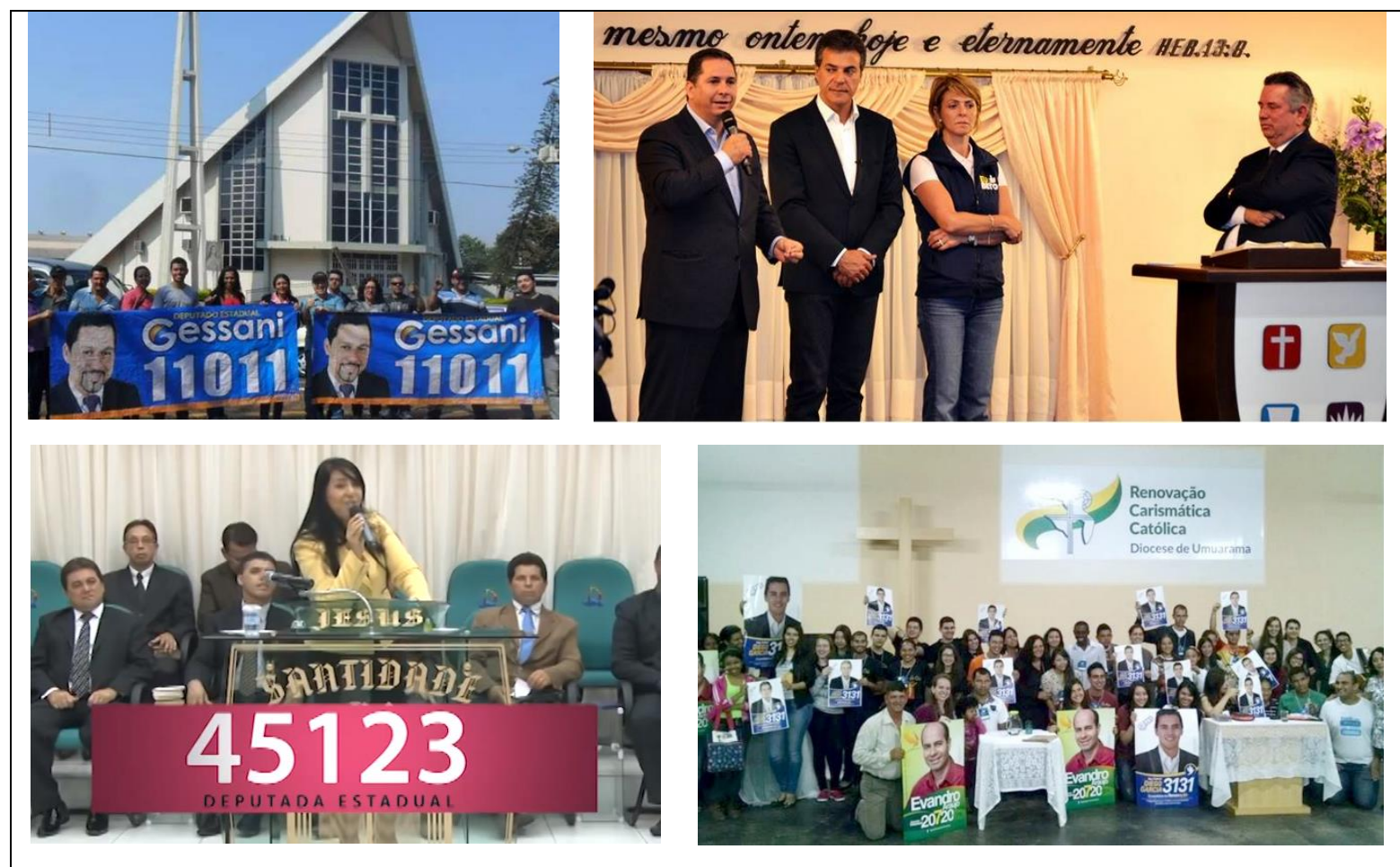

Fonte: Acervo do Grupo de Pesquisa Cultura e Relações de Poder.

- Pautas de campanha: compreendem as propostas dos candidatos que estão explicitamente ligadas às pautas morais da denominação religiosa, e que ficam evidenciadas em algumas campanhas, girando principalmente em torno de questões relacionadas à família - com defesas à "família tradicional” -, à sexualidade, à educação - inclusive reivindicando a leitura bíblica nas escolas - e à liberdade de expressão pública da religião, reforçando uma demanda comumente considerada conservadora (CARVALHO JÚNIOR; ORO, 2017; VITAL DA CUNHA; LOPES; LUI, 2017; ALMEIDA, 2017). No caso dos materiais analisados, essas pautas ficam mais explícitas nas campanhas de Queiroga, Clayton Costa Rosa, Dr. Ulisses e Gilson de Souza, embora seja possível inferir tais elementos na campanha de outros candidatos, como da Cantora Mara Lima, Pastor Edson Praczyk, Jura, Gessani e Evandro Araújo, entre outros. Ainda, há aqueles que se colocam explicitamente como representantes de determinadas igrejas, defendendo suas pautas no espaço público, como ocorre nas campanhas de 
Pastor João dos Anjos e Gilson de Souza. Se, por um lado, as pautas de tais campanhas expressam a compreensão do próprio candidato, podemos dizer que também confirmam uma sintonia e compromisso dos mesmos com a demanda religiosa, que sugerem assumir, muitas vezes, uma característica corporativa, na medida em que os interesses de ambos são alinhados no exercício do mandato do representante religioso, caso seja eleito (MACHADO, 2006). Os materiais de campanha do Quadro 5 expressam, em parte, as pautas aqui mencionadas.

Quadro 5: Materiais de campanha de Gessani, Clayton Costa Rosa, Gilson de Souza

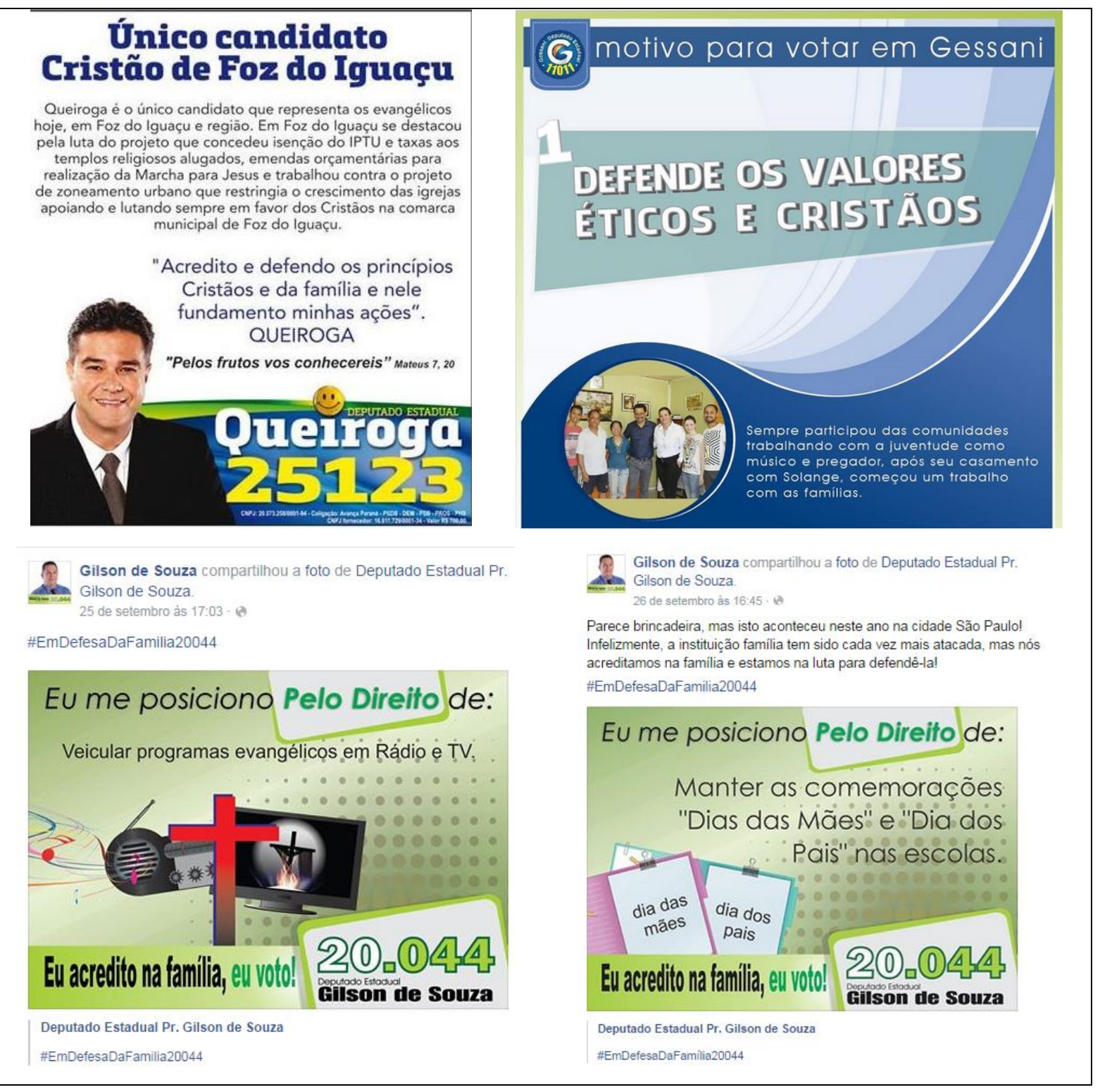




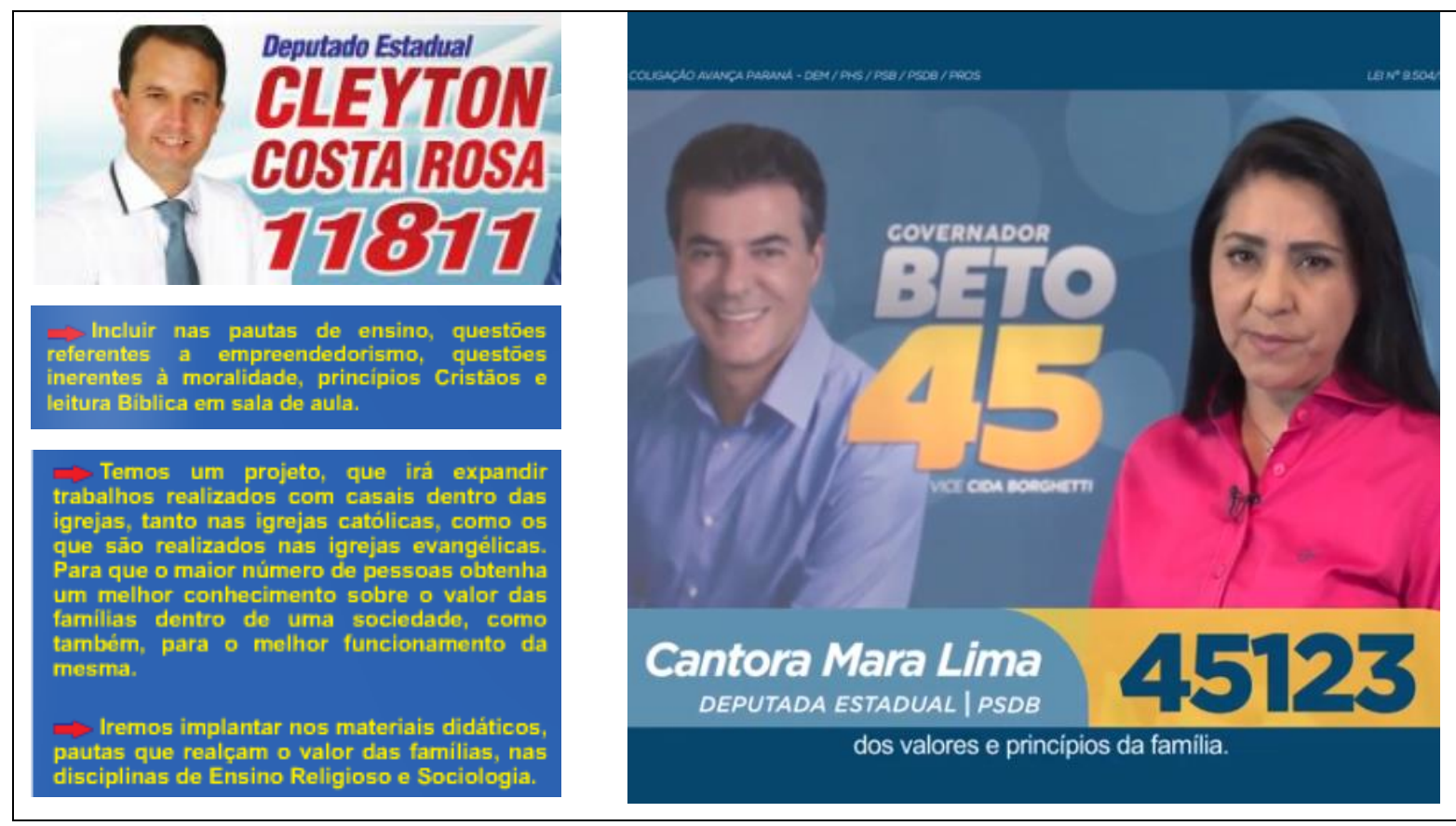

Fonte: Acervo do Grupo de Pesquisa Cultura e Relações de Poder.

\section{Forma de instrumentalização mútua entre religião e política}

Quanto à forma do acionamento religioso, destacamos as diferentes estratégias utilizadas pelos candidatos e pelas Igrejas na consolidação de suas campanhas. Nesse caso, percebe-se que, em quase todas as denominações, a candidatura assume um caráter oficial, vinculada à Igreja, como ocorre com a Igreja Católica (MFP/RCC) - Jura, Evandro Araújo e Gessani -; Assembleia de Deus - Noemia Rocha -; Igreja Universal do Reino de Deus - Pastor Edson Praczyk -; Igreja do Evangelho Quadrangular - Gilson de Souza -; Igreja Mundial do Poder de Deus - Missionário Ricardo Arruda - e Igreja Internacional da Graça de Deus - Dr. Ulisses. Os materiais de campanha apresentados no Quadro 6 evidenciam essa característica. Essa oficialidade implica em uma escolha planejada e deliberada por parte da instituição religiosa, bem como no uso de suas estruturas e de suas lideranças na realização e divulgação da campanha eleitoral. A partir dessa estratégia, além de dar legitimidade ao candidato por meio do apoio da religião, busca-se acionar o capital religioso da Igreja (BOURDIEU, 2007), em vista de obter votos nos mais diferentes municípios do estado, nos quais as Igrejas se fazem presentes - o que, de certa forma, ficou evidenciado nos dados de cada um dos candidatos. 
Quadro 6: Materiais de campanha de Gessani, Missionário Arruda, Pastor Edson Praczyk e Dr. Ulisses, evidenciando o apoio oficial de suas Igrejas

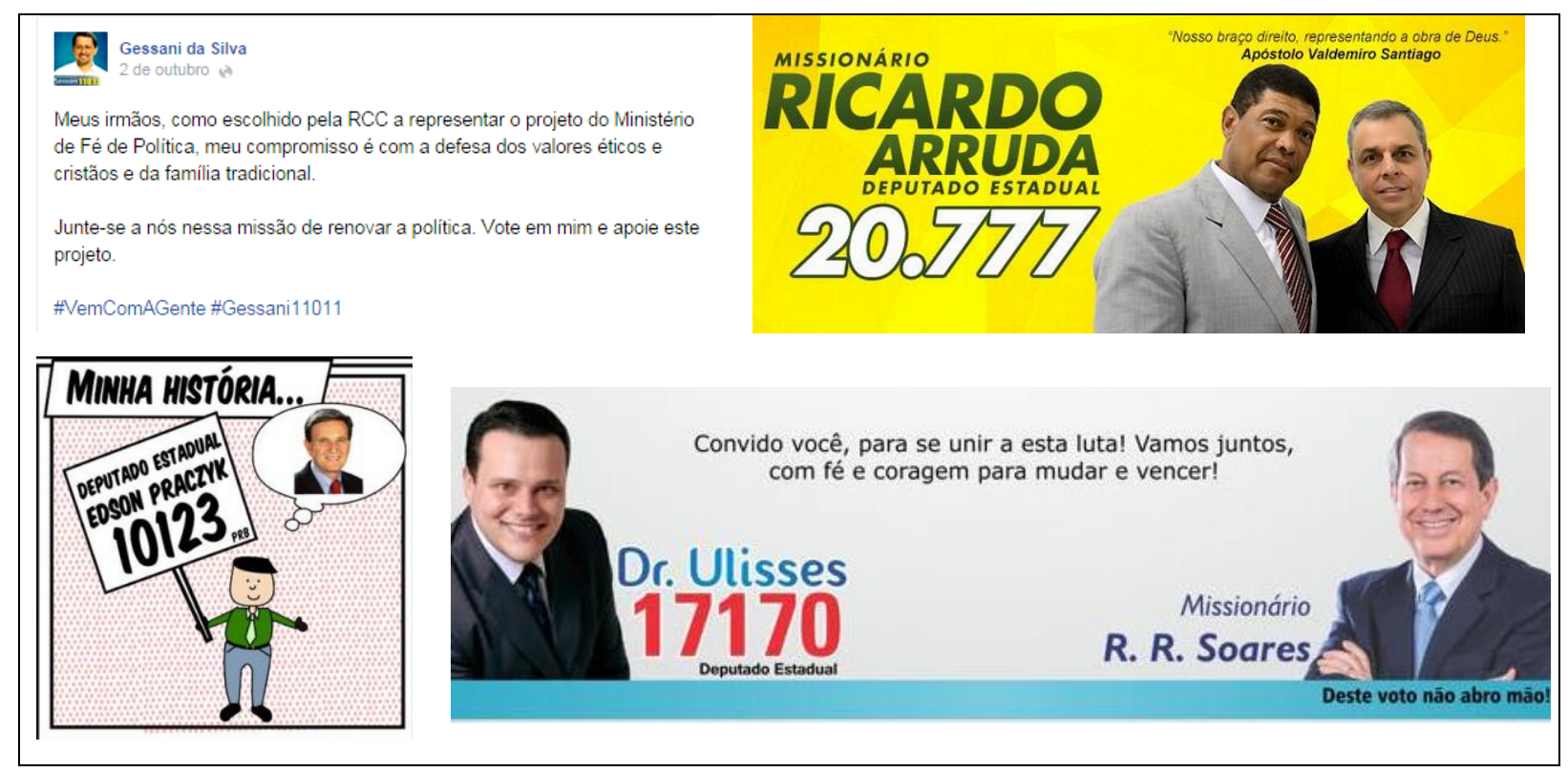

Fonte: Acervo do Grupo de Pesquisa Cultura e Relações de Poder.

Já no caso daqueles que não são assumidos oficialmente pelas Igrejas, é possível identificar da mesma forma a busca pelo apoio de seus líderes, a utilização recorrente de símbolos vinculados à religião, além do diálogo que o candidato estabelece com os fiéis de sua denominação, paralelamente à orientação dada institucionalmente pela cúpula da Igreja. Este é o caso de Padre Roque (Igreja Católica) e da Cantora Mara Lima (Assembleia de Deus), que, a despeito de não serem os candidatos oficiais de suas denominações, ainda assim instrumentalizam intensamente a religião em suas campanhas, seja no uso do nome/função que desempenham, seja pela recorrência a representações: a cruz, a bíblia, o templo, a linguagem.

A instrumentalização mútua entre religião e política pelos candidatos à ALEP permitem inferir diferentes lógicas das próprias instituições religiosas e as estratégias adotadas no tempo da política. Dessa maneira, enquanto algumas igrejas atuam de forma mais hierarquizada na indicação dos candidatos religiosos - como a Igreja do Evangelho Quadrangular, a Igreja Universal do Reino de Deus, a Igreja Mundial do Poder de Deus e a Igreja Internacional da Graça de Deus -, outras operam a partir de dinâmicas distintas como parece ser o caso da Assembleia de Deus, da Igreja Católica e das religiões de 
matriz afro-brasileira -, seja por ter um funcionamento mais descentralizado, com maior autonomia decisória de suas comunidades, seja pela complexidade da estrutura eclesiástica, ou mesmo por haver compreensões múltiplas acerca de como deveriam ser as relações entre religião e política. Em certa medida, as diferentes estruturas e estratégias de atuação das Igrejas em tempo de eleição já vêm sendo apontadas por outros autores que tematizam a presença pública da religião, de modo que esse movimento, identificado no cenário paranaense, tem ocorrido também de forma semelhante em outros espaços (ORO, 2003; SCHOENFELDER, 2006; SILVEIRA, 2008).

\section{Considerações finais}

Tendo em vista as configurações e apoios que já começam a se delinear para as próximas eleições, buscamos, neste artigo, analisar de que forma a religião foi acionada nas candidaturas de agentes religiosos para a disputa à ALEP em 2014. No referido pleito, pudemos identificar um total de 26 candidatos que, com diferentes intensidades, estilos e formas, fazem uso de elementos religiosos como estratégia de campanha. Embora não possamos estabelecer uma relação entre tais acionamentos e o êxito eleitoral, é certo que diferentes grupos sociais recorrem ao campo religioso, onde procuram estabelecer alianças, cumplicidades e apoios para potencializar suas campanhas eleitorais. Por outro lado, é flagrante que as próprias Igrejas têm se organizado no sentido de lançar seus candidatos - oficiais ou não -, buscando eleger representantes para ocupar as vagas no legislativo do Estado. Vale ressaltar que, especificamente no caso do campo político paranaense - solo fértil, ao que parece, para os estudos acerca da porosidade de fronteiras entre política e religião -, trata-se de um lócus ainda pouco explorado, e que merece investigações futuras, em especial no que tange à forma como são construídas as alianças entre os diferentes grupos - religiosos ou não - presentes na esfera pública.

Considerando que a pesquisa buscou inventariar empiricamente os candidatos e as instituições religiosas que já vêm estabelecendo relações e apoios mútuos na esfera da política, entendemos que o movimento desta pesquisa contribui para a compreensão dos próximos pleitos eleitorais, na medida em que identifica os sujeitos envolvidos, evidencia as estratégias e alianças entre diferentes partidos políticos e grupos sociais e, ainda, 
busca sistematizar alguns elementos comuns às campanhas eleitorais de agentes religiosos, e que podem ser úteis para balizar novas análises. Tal iniciativa se dá na esteira de um entendimento, já expressado por Sanchis (2001), de que as religiões, na atualidade, não vão mais deixar de articular-se visivelmente à política. Trata-se, portanto, de uma dinâmica que não pode mais ser ignorada pelo olhar daqueles que se debruçam sobre a compreensão das lógicas que operam na sociedade contemporânea.

\section{Referências}

ALMEIDA, Ronaldo. A onda quebrada - evangélicos e conservadorismo. Cadernos Pagu, Campinas, n. 50, p. 1-27, 2017.

BANDINI, Claudirene. Religião e política: a participação política dos pentecostais nas eleições de 2002. Dissertação (Mestrado em Ciências Sociais). Universidade Federal de São Carlos, São Carlos, 2004.

BOURDIEU, Pierre. A economia das trocas simbólicas. São Paulo: Perspectiva, 2007.

CARVALHO JUNIOR, Erico Tavares de; ORO, Ari Pedro. Eleições municipais 2016: religião e política nas capitais brasileiras. Debates do NER, Porto Alegre, ano 18, n. 32, p. 15-68, jul./dez., 2017.

CERVI, Emerson Urizzi. O "Tempo da política” e a distribuição de recursos partidários: uma análise do HGPE. Revista em debate, Belo Horizonte, v. 2, n. 8, p. 12-17, 2010.

GIUMBELLI, Emerson. O acordo Brasil-Santa Sé e as relações entre estado, sociedade e religião. Ciencias Sociales y Religión, Porto Alegre, ano 13, n. 14, p. 119-143, set., 2011.

GIUMBELLI, Emerson. 0 fim da religião: dilemas da liberdade religiosa no Brasil e na França. São Paulo: Attar: CNPq/Pronex, 2002.

IBGE. Censo 2010. Rio de Janeiro, 2010. Disponível em: <https://censo2010.ibge.gov.br/>. Acesso em: 14 ago. 2018.

IBGE-Cidades. Brasil em síntese. Rio de janeiro, 2018. Disponível em: https://cidades.ibge.gov.br/. Acesso em: 14 ago. 2018. 
MACHADO, Maria das Dores Campos. Política e religião: a participação dos evangélicos nas eleições. Rio de Janeiro: FGV, 2006.

MARIANO, Ricardo. Laicidade à brasileira: católicos, pentecostais e laicos em disputa na esfera pública. Civitas, Porto Alegre, v. 11, n. 2, p. 238-258, maio/ago., 2011.

MIRANDA, Julia. O candidato da igreja: do que nos fala a sua presença na política brasileira. In: LEMENHE, Maria Auxiliadora; CARVALHO, Rejane Vasconcelos Accioly. Política, cultura e processos eleitorais. Rio de Janeiro: Konrad Adenauer Stiftung, 2006, p. $149-170$.

ORO, Ari Pedro. Religião e política nas eleições 2000 em Porto Alegre. Debates do NER, Porto Alegre, ano 2, n. 3, 2001.

ORO, Ari Pedro. A política da Igreja Universal e seus reflexos nos campos religioso e político brasileiros. Revista Brasileira de Ciências Sociais, São Paulo, v. 18, n. 53, p. 53-69, 2003.

ORO, Ari Pedro; CARVALHO JUNIOR, Erico Tavares. Eleições gerais de 2014: religião e política no Rio Grande do Sul. Debates do NER, Porto Alegre, v. 27, p. 145-171, 2015.

ORO, Ari Pedro; MARIANO, Ricardo. Eleições 2010: religião e política no Rio Grande do Sul e no Brasil. Debates do NER, Porto Alegre, ano 10, n. 16, p. 9-34, jul./dez., 2009.

PALMEIRA, Moacir. Política e tempo: nota exploratória. In: PEIRANO, Mariza. (Org.). 0 dito e o feito: ensaios de antropologia dos rituais. Rio de Janeiro: Ed. Relume Dumará, 2002, p. 171-177.

PROCÓPIO, Carlos Eduardo. Perto da religião, perto da política: a participação do catolicismo carismático através da instituição, candidaturas e mídia nas eleições de 2010. Tese (Doutorado em Ciências Sociais). Universidade Federal de Juiz de Fora, Juiz de Fora, 2014.

RCC/BRASIL. Fé e política: conceitos e abordagens. Canas: RCC/BRASIL, 2016.

RCC/PR. Projeto de acompanhamento dos vocacionados da RCC nas eleições 2014 para deputado estadual e federal. Curitiba, 2013.

SANCHIS, Pierre. Desencanto e formas contemporâneas do religioso. Ciencias Sociales y Religión, Porto Alegre, año 3, n. 3, p. 27-43, oct., 2001. 
SCHOENFELDER, Rosilene; PAZ, Joice Lisa. A Igreja do Evangelho Quadrangular nas eleições de 2006: a disputa pela vaga de deputado federal. Debates do NER, Porto Alegre, ano 7, n. 10, p. 27-37, jul./dez., 2006.

SILVEIRA, Emerson José Sena. Terços, santinhos e versículos: a relação entre católicos carismáticos e a política. Revista de Estudos da Religião, São Paulo, ano 8, p. 54-74, 2008.

TRIBUNAL SUPERIOR ELEITORAL - TSE -. Eleições 2014. Brasília, 2014. Disponível em: http://www.tse.jus.br/eleitor-e-eleicoes/eleicoes/eleicoes-anteriores/eleicoes2014/eleicoes-2014. Acesso em: 14 ago. 2018.

VITAL DA CUNHA, Christina; LOPES, Paulo Victor Leite; LUI, J. Religião e política: medos sociais, extremismo religioso e as eleições 2014. Rio de Janeiro: Fundação Heinrich Böll: Instituto de Estudos da Religião, 2017. 